\title{
Nested-PCR using MPB64 fragment improves the diagnosis of pleural and meningeal tuberculosis
}

\author{
Nested-PCR usando o fragmento MPB64 melhora o \\ diagnóstico da tuberculose pleural e meníngea
}

\author{
Luiz C. Martins ${ }^{1}$, Ilma A. Paschoal ${ }^{2}$, Angela Von Nowakonski ${ }^{3}$, Silvana A.B. Silva ${ }^{4}$, \\ Fernando F. Costa ${ }^{4}$ and Laura Sterian Ward ${ }^{5}$
}

\begin{abstract}
Fluids in which Mycobacterium tuberculosis are seldom found, such as pleural and cerebrospinal liquids, are good candidates to be studied using PCR techniques. We detail our experience with a PCR assay applied to pleural and cerebrospinal fluids using the primer MPB64. Seventy three specimens were analyzed: 30 pleural fluids (PF), 26 pleural biopsies (PB) and 17 cerebrospinal fluids (CSF). The gold standard for the diagnosis of tuberculous meningitis was the positive culture for M. tuberculosis in CSF. Tuberculous pleural effusion was diagnosed when cultures of $P F$ and/or $P B$ were positive for $M$. tuberculosis, or the $P B$ histology showed granulomas. Our results, compared to the gold standards employed, showed a sensitivity of $70 \%$, specificity of $88 \%$, positive predictive value of $82 \%$ and negative predictive value of $80 \%$. The high specificity of the MPB64 fragment while still retaining a good sensitivity makes it very well suited for pleural and cerebrospinal tuberculosis diagnosis.
\end{abstract}

Key-words: Tuberculosis. Diagnosis. PCR technique. Central nervous system. Pleura.

Resumo $O$ Mycobacterium tuberculosis é raramente encontrado em fluidos como o líquido pleural e o cérebroespinhal, tornando estas localizações de difícil diagnóstico. Apresentamos nossa experiência com uma técnica de PCR aplicada a líquido pleural e cerebroespinhal com o uso do primer MPB64. Sessenta e três espécimes foram analisados: 30 líquidos pleurais (PF), 26 biópsias pleurais (PB) e 17 líquidos cerebroespinhais (CSF). O gold standard para o diagnóstico de meningite tuberculosa foi a cultura positiva para M. tuberculosis no CSF. Tuberculose pleural era diagnosticada quando culturas do PF e/ou PB eram positivas para M. tuberculosis, ou a histologia da PB mostrava granulomas. Nossos resultados, comparados aos gold standards empregados, mostram sensitividade de $70 \%$, especificidade de $88 \%$, valor preditivo positivo de $82 \%$ e valor preditivo negativo de $80 \%$. A elevada especificidade e boa sensibilidade do fragmento MPB64 o transformam em um bom parâmetro para o diagnóstico de tuberculose pleural e do líquido cérebroespinhal.

Palavras-chaves: Tuberculose. Diagnóstico. Técnica de PCR. Sistema nervoso central. Pleura.

\footnotetext{
1. Medical School, Marilia, SP, Brazil. 2. Pulmonary Disease Department, Universidade de Campinas, Campinas, SP, Brazil. 3. Department of Clinical Pathology, UNICAMP, Campinas, SP, Brazil. 4. Hematology, UNICAMP, Campinas, SP, Brazil. 5. Internal Medicine, UNICAMP and Laboratory of Cancer Molecular Genetics-FCM/UNICAMP, Campinas, SP, Brazil.

Address to: Dra Laura Sterian Ward. GEMOCA/Med Int/Clin Med/FCM/UNICAMP, Cidade Universitária Zeferino Vaz, 13083-970 Campinas,

São Paulo State, Brazil.

Telefax: 5519 289-4107.

e-mail: ward@unicamp.br

/Recebido para publicação em 16/7/99
} 
Tuberculosis continues to be a serious health problem in Brazil and, likewise in other countries, the number of cases is increasing in patients with human immunodeficiency virus (HIV) infection ${ }^{6}$. Pleural and central nervous system tuberculosis are frequently suspected in these patients and we often have to deal with these challenging diagnoses in our service. Laboratory methods play a crucial role in establishing the diagnosis and monitoring the therapy. In order to establish a conclusive diagnosis of tuberculosis it is necessary to demonstrate the presence of the Mycobacterium tuberculosis in body fluids or tissues. Microscopy for acid-fast bacilli is, at present, the mainstay of routine clinical laboratories for any rapid diagnostic approach to a patient under clinical suspicion of tuberculosis. However, the technique has low sensitivity and cannot identify the Mycobacterium species $^{7}$. Traditional culture methods with identification of the causative Mycobacterium continue to be considered definitive in terms of diagnosis. However, these techniques are laborious and may take as long as 12 weeks to yield results ${ }^{37}$. Besides, the sensitivity of the culture can be as low as $50 \%$ or less ${ }^{37}$. Radiometric culture systems may improve the sensitivity and are faster but they still require at least 2 weeks to confirm the diagnosis and are expensive ${ }^{11}$. With the development of new techniques, such as the detection of microorganisms by hybridization with probes, introduced in the 1970 s, and immunological procedures, limitations in the sensitivity and/or specificity of established techniques have become apparent ${ }^{13}$. Hence, molecular amplification technology emerged as the most revolutionary development to reach clinical and virology laboratories this decade. The advent of nucleic acid probe methods, more than a decade ago, was welcomed as a way to speed up the identification problem. However, it soon became clear that a more sensitive detection method amplifying the targets when only very few specimens were present was needed ${ }^{2}$. PCR-based amplification methods allow the search for organism-specific nucleic acid sequences regardless of the physiological requirements or viability of the organism. In some situations, such as in pleural or cerebrospinal infection, PCR stands out because of its speed, sensitivity and specificity ${ }^{151618}$. A recent evaluation of PCR sensitivity using the primers described by Eisenach et al ${ }^{5}$ suggest that it allows the detection of three copies of the M. tuberculosis genome $/ \mathrm{ml}^{15}$. The method may therefore be used for the early detection of $M$. tuberculosis growth on liquid medium. We present here a reliable, simple and fast PCR method for tuberculosis detection in human fluids.

\section{MATERIAL AND METHODS}

Seventy-three specimens were obtained from 56 patients of the Hospital das Clínicas - Medical Science Faculty of the State University of Campinas (UNICAMP) São Paulo, Brazil. Thirty were pleural fluids (PF), 26 pleural biopsies (PB) and 17 cerebrospinal fluids (CSF). All patients presented exudative pleural effusions or symptoms of meningeal disease. In both circumstances, tuberculosis had to be ruled out. After signing an informed consent, the patients had their clinical specimens analyzed using bacterioscopy, traditional culture methods, microscopic examination of the pleural biopsies and PCR. The gold standard used for the diagnosis of meningeal tuberculosis was the positive culture for M. tuberculosis in the cerebrospinal fluid. For pleural tuberculosis, we considered positive those specimens with positive culture for M. tuberculosis in the pleural fluid and/ or in the biopsy or the demonstration of granulomas in the biopsy fragment ${ }^{151618}$. The fragments of pleural biopsies were cultured, typed for Mycobacterium tuberculosis and also submitted to histologic examination.
Two DNA extraction methods were used: one, simple and fast consisted of heating the sample during 10 minutes at $100^{\circ} \mathrm{C}$. Afterwards, the samples were used directly in the PCR reaction (PCR1). In parallel, we extracted DNA from another aliquot of the same sample using proteinase $\mathrm{K}$ over-night digestion, phenol/ chloroform extraction and ethanol precipitation $(\text { PCR2 })^{14}$. We used a specific 240bp primer set of primers for the complex M. tuberculosis/bovis, a fragment called MPB64: sense 5' TCC GCT GCC AGT CGT CTT CC 3'and antisense 5'GTC CTC GCG AGT CTA GGC CA 3'4 8. The PCR products obtained were not satisfactory, possibly because most of the samples had less than 10100 tubercle bacilli. Therefore, we designed another pair of primers to amplify an inner sequence: sense 5'ATT GTG CAA GGT GAA CGT AG 3'and antisense primer 5'AGC ATC GAG TCG ATC GCG GA 3'. PCR mixtures were prepared with $10 \mu \mathrm{l}$ of the product of the extraction, $50 \mathrm{pmol}$ of each primer, $100 \mu \mathrm{M}$ dNTPs, $10 \mathrm{mM}$ Tris 
$\mathrm{HCl}\left(\mathrm{pH}=9.0\right.$ at $\left.25^{\circ} \mathrm{C}\right), 50 \mathrm{mM} \mathrm{KCl}, 1,5 \mathrm{mM}$ $\mathrm{mGC12}$, and $4 \mathrm{U}$ Taq polymerase (Promega Co, Madison, WI) in a final volume of $100 \mu \mathrm{l}$. Amplifications were carried out for 35 cycles with 1 minute denaturation at $94^{\circ} \mathrm{C}, 55^{\circ} \mathrm{C}$ annealing for 1.5 minutes and primer extension at $72^{\circ} \mathrm{C}$ for 3 minutes. We used a sample of distilled water as a negative control and samples of $M$. tuberculosis DNA extracted from a known culture (strain H37 from Institute Adolpho Lutz, Brazil) as positive controls. In order to perform a nested PCR, an aliquot of $10 \mu \mathrm{l}$ was removed from the initial reaction and directly added to the new reaction, carried out for 30 cycles at $94^{\circ} \mathrm{C}$ for 1 minute, $55^{\circ} \mathrm{C}$ for 1 minute and $72^{\circ} \mathrm{C}$ for 1 minute. PF and CSF samples were also cultured in the egg-based (Lowenstein-Jensen) media and the culture supernatant was also used in the PCR. The PCR products were then analyzed by electrophoresis using a $2 \%$ agarose gel stained with ethidium bromide and examined under ultraviolet light.

Statistical analysis. Data were analyzed by the $\chi^{2}$ test. The level of significance was taken as $p<0.05$. The sensitivity, specificity, positive and negative predictive values of the proposed test were calculated according to standard methods ${ }^{10}$.

\section{RESULTS}

The results of all methods for pleural tuberculosis diagnosis are compared in Table 1.
Among the 19 cases investigated, 6 were positive with PCR1 and 13 cases were positive with PCR2.

Table 1 - Pleural tuberculosis diagnostic methods comparison: gold standard procedures (pleural fluid culture, biopsy culture and granuloma detection in the biopsy), PCR 1 (without phenol/chloroform extraction) and PCR2 (with phenol/ chloroform extraction). The sensitivity of each method is showed in the last line of the table.

\begin{tabular}{|c|c|c|c|c|c|}
\hline № & $\begin{array}{c}\text { Pleural fluid culture } \\
\%\end{array}$ & $\begin{array}{c}\text { Biopsy culture } \\
\% \\
\end{array}$ & $\begin{array}{c}\text { Granuloma in the biopsy } \\
\%\end{array}$ & $\begin{array}{c}\text { PCR } 1 \\
\%\end{array}$ & $\begin{array}{c}\text { PCR } 2 \\
\%\end{array}$ \\
\hline 1 & + & - & + & + & + \\
\hline 2 & - & - & + & - & - \\
\hline 3 & - & + & + & + & + \\
\hline 4 & - & + & + & - & + \\
\hline 5 & + & - & + & - & + \\
\hline 6 & - & - & + & - & - \\
\hline 7 & + & - & + & - & + \\
\hline 8 & - & - & + & - & - \\
\hline 9 & + & + & + & + & + \\
\hline 10 & - & - & + & - & - \\
\hline 11 & - & + & + & - & + \\
\hline 12 & + & + & 0 & + & + \\
\hline 13 & - & + & 0 & - & + \\
\hline 14 & + & - & + & - & + \\
\hline 15 & - & + & 0 & + & + \\
\hline 16 & - & + & + & - & + \\
\hline 17 & - & + & + & - & - \\
\hline 18 & - & + & + & - & - \\
\hline 19 & - & + & + & + & + \\
\hline Total & 31.6 & 57.9 & 100 & 31.6 & 68.4 \\
\hline
\end{tabular}

+ positive; - negative; 0 not done

In Table 2 we compare the results of the two extraction methods used: PCR1 and PCR2, in the diagnosis PF and CSF. Seven cases out of the 19 positive PF were detected with PCR1 and 14 with PCR2. Just 1 sample of CSF was positive according to the gold standard, but 3 could be detected by
PCR1 and also by PCR2 (the same three cases), suggesting these patients could be harboring a tuberculosis disease not detectable by standard means. PCR2 extraction method provided better results than the PCR1 method $\left(\chi^{2} ; p<0.01\right)$. 
Table 2 - Comparison of positivity among gold standard diagnostic, PCR 1 (without phenol/chloroform extraction) and PCR2 methods (with phenol/chloroform extraction) for Pleural (PF) and Cerebrospinal (CSF) Fluids. PCR2 extraction method provided better results than the PCR1 method $\left(\chi^{2} ; p<0.01\right)$.

\begin{tabular}{lccc}
\hline & Gold standard & PCR 1 & PCR 2 \\
\hline PF $(n=30)$ & 19 & 7 & 14 \\
CSF $(n=17)$ & 1 & 3 & 3 \\
\hline
\end{tabular}

Table 3 shows PCR2 results compared with gold standard methods for both pleural and meningeal tuberculosis. Using this nested PCR method, we achieved a sensitivity of $70 \%$, specificity of $88 \%$, positive predictive value of $82 \%$ and negative predictive value of $80 \%{ }^{10}$. These data were not different in the CSF group compared with PF group ( $\chi^{2}$; not significant).

Table 3 - MPB64 nested-PCR diagnostic power: sensitivity = 70\%; specificity = 88\%; positive predictive value=82\%; negative predictive value $=80 \%$.

\begin{tabular}{lccc}
\hline PCR samples & $\begin{array}{c}\text { Positive } \\
\text { gold-standard }\end{array}$ & $\begin{array}{c}\text { Negative } \\
\text { gold-standard }\end{array}$ & Total \\
\hline Positive & 14 & 3 & 17 \\
Negative & 6 & 24 & 30 \\
\hline Total & 20 & 27 & 47 \\
\hline
\end{tabular}

\section{DISCUSSION}

Although considered primarily a pulmonary disease, tuberculosis can affect any organ system. Central nervous system involvement is potentially devastating and occurs with escalating frequency in both immunocompetent and immunologically incompetent populations. When we are dealing with specimens such as pleural and cerebrospinal fluids, known for their little positivity in bacterioscopy, most commonly used diagnostic methods present low sensitivity and/or are time consuming. Culture and histology exam of fragments obtained by pleural biopsy can increase the accuracy of the diagnosis, however they require an invasive procedure. Microscopic examination of CSF for acid-fast bacilli also has low sensitivity in meningeal tuberculosis and, especially in patients without AIDS, positive results are rare ${ }^{9}$. On the other hand, pleural and meningeal tuberculosis need to be promptly and reliably diagnosed. PCR techniques emerged as a very useful implement in these cases augmenting the diagnosis sensitivity dramatically ${ }^{3}$. Moreover, M. tuberculosis detection by molecular methods may also play a role in laboratory safety and, therefore, in laboratory costs, since after the initial extraction procedure, only non-infectious materials are handled ${ }^{15}$. PCR is expected to be more specific and sensitive than the routine procedure for diagnosis, but it is also more costly ${ }^{1}$. Cost-effectiveness comparisons of
PCR versus smear examination showed no advantages of the former for the diagnosis of tuberculosis ${ }^{12}$. However, PCR can be of great value detecting very few bacilli when a rapid diagnosis is imperative, like in pleural and meningeal infections. Also, the largest contributing cost component is the cost of the PCR-kit ${ }^{12}$. We may be able to substantially reduce this cost standardizing home-made methods. New studies involving fine needle aspirates may also be envisaged, improving the diagnosis in many cases ${ }^{17}$.

MPB-64 insertion element has been widely demonstrated to be highly specificity for the M. tuberculosis complex ${ }^{48}$. Tested against the IS6110 and the 65Kda HSP fragments, it gave less false positive results ${ }^{8}$. Some handicaps had to be overcome, such as the challenging mycobacterium DNA extraction from liquids where bacilli are very sparse. Phenolchloroformproteinase $\mathrm{K}$ method provided a material of good quality for PCR. The use of a nested amplification increased both sensitivity and specificity of the PCR process.

In conclusion, we validated a nested-PCR technique using MPB64 fragment in the diagnosis of pleural and meningeal tuberculosis in our specimens, confirming it to be a powerful diagnostic tool with a good sensitivity (70\%), a high specificity $(88 \%)$, positive predictive value of $82 \%$ and negative 
predictive value of $80 \%$. We demonstrated that the method is reliable, fast and specific, comparing positively with all other similar methods reported in the literature ${ }^{458}$.

\section{REFERENCES}

1. Bollela VR, Sato DN, Fonseca BA. McFarland nephelometer as a simple method to estimate the sensitivity of the polymerase chain reaction using Mycobacterium tuberculosis as a research tool. Brazilian Journal of Medical and Biological Research 32:10731076, 1999.

2. Cousins D, Francis B, Dawson D. Multiplex PCR provides a low-cost alternative to DNA probe methods for rapid identification of Mycobacterium avium and Mycobacterium intracellulare. Journal of Clinical Microbiology 34:23312333, 1996.

3. Daniel TM. The rapid diagnosis of tuberculosis: A selective review. Journal of Laboratory and Clinical Medicine 116:277-282, 1990.

4. Dar L, Sharma SK, Bhanu NV, Broor S, Chakraborty M, Pande JN, Seth P. Diagnosis of pulmonary tuberculosis by polymerase chain reaction for MPB64 gene: an evaluation in a blind study. Indian Journal of Chest Diseases and Allied Sciences 40:5-16, 1998.

5. Eisenach KD, Cave MD, Bates JH, Crawford JT. Polymerase chain reaction amplification of a repetitive DNA sequence specific for Mycobacterium tuberculosis. Journal of Infectious Diseases 161: 977-981, 1990.

6. Havlir DV, Barnes PF. Tuberculosis in patients with human immunodeficiency virus. New England Journal of Medicine 340:367-373, 1999.

7. Heifets LB, Good RC. Current laboratory methods for the diagnosis of tuberculosis. In:Bloom BR (ed) Tuberculosis: pathogenesis, protection and control. ASM Press, Washington, DC, p. 85-110, 1994.

8. Lee BW, Tan JA, Wong SC, Tan CB, Yap HK, Low PS, Chia JN, Tay JS. DNA amplification by the polymerase chain reaction for the rapid diagnosis of tuberculosis meningites. Comparison of protocols involving three mycobacterial DNA sequences, IS 6110,65 Kda antigen and MPB 64. Journal of the Neurological Sciences 123:173-209, 1994.

9. Light RW, Ferrer J. Diagnosis of pleural tuberculosis. Archivos de Broconeumologia 35:105-107, 1999.
10. Lopez-Jimenez F, Rohde LE, Luna-Jimenez MA. Problems and solutions in the interpretation of diagnostic tests. Revista de Investigacion Clínica 50:65-72, 1998.

11. Morgan MA, Horstmeier CD, DeYoung DR, Roberts GD. Comparison of a radiometric method (BACTEC) and conventional media for recovery mycobacterium from smear negative specimens. Journal of Clinical Microbiology 18:384-388, 1983.

12. Roos BR, van Cleeff MR, Githui WA, Kivihya-Ndugga L, Odhiambo JA, Kibuga DK, Klatser PR. Cost-effectiveness of the polymerase chain reaction versus smear examination for the diagnosis of tuberculosis in Kenya: a theoretical model. International Journal of Tuberculosis and Lung Diseases 2:235-241, 1998.

13. Roth A, Schaberg $T$, Mauch $H$. Molecular diagnosis of tuberculosis: current clinical validity and future perspectives. European Respiratory Journal 10:18771891, 1997.

14. Sambrook J, Fritsh EF, Maniatis T. Molecular Cloning: Harbor Laboratory Press, 1989.

15. Sandin RL Polymerase chain reaction and other amplification techniques in microbacteriology. In: Heifits $\mathrm{L}$ (ed) Clinics and laboratory medicine. Clinical mycobacteriology. Philadelphia, WB Saunders, p.617640, 1996.

16. Schluger NW, Rom WN. The polymerase chain reaction in the diagnosis and evaluation of pulmonary infections. American Journal of Respiratory and Critical Care Medicine 152:11-6, 1995.

17. Shim JJ, Cheong HJ, Kang EY, Yoo SH, Kang KH. Nested polymerase chain reaction for detection of Mycobacterium tuberculosis in solitary pulmonary nodules. Chest 113:2024, 1998.

18. Takagi N, Hasegawa $\mathrm{Y}$, Ichiyama S, Shibagaki T, Shimokata K. Polymerase chain reaction of pleural biopsy specimens for rapid diagnosis of tuberculous pleuritis. International Journal of Tuberculosis and Lung Diseases 2:338-341, 1998. 